\title{
治療過程における心理療法家の属性に関する研究 意味のあるクライエントの動きの評価について—
}

東京都立大学 永井撤 ${ }^{1}$

A study of attributes of psychotherapists through the therapeutic process : Evaluations of the meaningful actions of clients

Tohru Nagai (Department of Psychology, Faculty of Social Sciences and Humanities, Tokyo Metropolitan University, Meguro-ku, Tokyo 152)

This study sought to clarify the therapeutic process through the evaluation of clients' meaningful action and to investigate possible relationships between the attributes of therapists and the therapeutic process. Two hundred and one therapists participated in the study by answering an inventory which evaluated the meaningful actions of clients. This inventory consisted of 47 items of therapeutic situations which were judged using a six-point scale. Factor-analysis resulted in seven factors: 1) resistance and inner conflict, 2) stable and reliable relationship, 3) autonomy, 4) disclosure, 5) activeness, 6) relaxation, 7) tension. The possible relationships were investigated between the therapists' attributes (such as his vocational standpoint, age, sex, clinical experience, therapeutic approach and the client's type of disorder and age) and each of these factors. Using the results of the inventory, 22 therapists were requested to arrange these seven factors in an order which reflects the process of their psychotherapy. The usual order was (7)(1)-(2)-(4)-(6)-(5)-(3). The importance which the therapists gave to each specific stage of the therapeutic process with a client was found to be related to the therapist's attributes.

Key words : psychotherapist, client's action, therapeutic process, therapist's attribute, factor analysis.

心理療法に対する関心が社会的にも非常に高まってき ている今日において, 治療理論や治療技法についての研 究が進められ, 数多くの新しい治療理論が提唱され, 新 しい治療技法が開発されてきている。しかし，そのよう な理論や技法の発展とともに，忘れてならないことは， 心理療法に括いて治療者とクライエントの人間関係が非 常に重要な役割を担っているといらことである。つま り,この人間関係があればこそ, クライエントの問題が 解決可能となるのである.このような心理療法に打い て, 当然, そこで治療者自身の人間性が治療にとって大 きな影響を与兄るものと考学ることができる．精神分析 に打いて，治療者になるための条件として自らクライエ ントの立場になり教育分析を受ける意味も，このような ところにあると考它らる。，本研究では，このような考

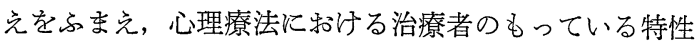
を明らかにしようとするものである。

1 本研究の調査に御協力いただいた臨床家の諸先生方 に厚く感謝の意を表します。また本論文作成にあたり， 東京都立大学詫摩武俊教授, 横浜国立大学小川捷之教授 の御指導賜り記して深謝いたします。
治療者のパーソナリティが治療効果に及ぼす影響につ いて, Whitehorn \& Betz (1954, 1957, 1960) は一連 の研究の中で, A-B scale と呼ばれる質問紙から分裂病 の患者に対する治療効果の高い治療者のタイプを明らか にしている. 一方, McNair, Collahan, \& Lorr (1962) は, 神経症レベルの患者の治療に適している治療者の夕 イプを明らかにしている.その後も, 治療者のタイプとク ライェントの適性についての研究がなされ, 治療効果に 治療者のパーソナリティが影響を及ぽしている結果を見 いだしている (Berzins \& Seidman, 1968, 1969 ; Berzins \& Ross, 1972 ; 西園, 1974 ; King \& Blaney, 1977).これは心理療法の効果が，技術以前の治療者の もつ人間性によって限界づけられていると言らことがで きる.しかし，ららがえすと，心理療法とはそれだけ治 療者とクライエントの人間性の不変的な部分での交流に よって，はじめて効果をもつものであると言うことがで きる。

治療理論や治療技法の違いが実際の治療に执いて，ぞ のような効果をもつのか研究したものに, Fiedler (1950) の精神分析, 非指示的方法, アドラー療法の治療者の比 
Table 1

Distribution of therapists rated each attribute of the therapists

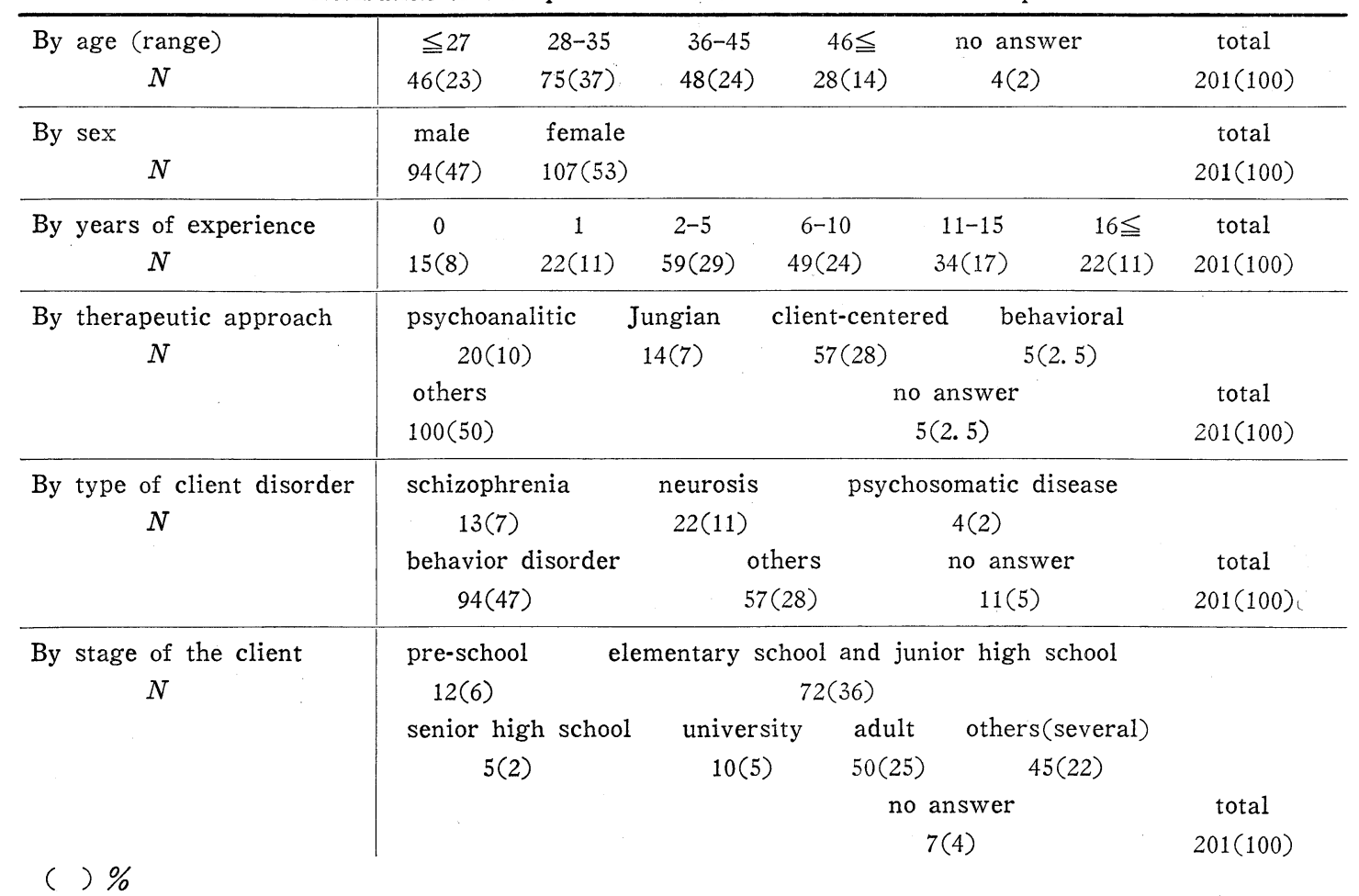

較研究がある. その結果, 立場の違いよりも経験年数が 重要な要因として作用していることが明らかとなった. Strupp (1955) は, 反応様式の分析から精神分析と来談 者中心療法の治療者の特徵的な違いを見いだしている. 小川・河合・原野・伊東・小川（1969）は，ある治療 理論なり治療技法なりを選択することに沶いて, 治療者 の内的資質の志向性が反映するのではないかという仮説 のもとに, Jung のタイプ論に基づいてQテクニックを 用いた数量的な研究を行い，同じ立場を選択する治療者 のタイプに共通性を見いだしている. Witzing (1978) も心理療法の立場と治療者のタイプについて, その関連 性を体系的に考察している. また, 河合 (1982) は Jung のタイプ論の文献的展望の中で, タイプ論を指標とした 治療者とクライエントの関係について論じて打り, 今後 の実証的研究の重要性を指摘している.

以上のように, 治療者自身の研究は種々の側面からな されており,ある側面からだけの研究で治療者を特徽づ けることはできない. 小川・永井 (1980) では, 比較研 究の難しい治療者の特徽を明らかにするための方法とし て, 治療者がクライエントのどのよらな動きに対し, 治 療的意味があると認めるか, その因子構造を明らかにし た. その結果, (1)自己信頼への動き, (2)内的な䓪藤・緊
張の動き, (3)柔軟性の動き, (4)自己開放の動き, (5)独立 性の動き, (6)望ましい関係の形成, (7)自信と安定, (8)自 律性, 9治療者との安心した関係の形成, (10)依存的な動 き, (11)内的な力の現われ, 以上の 11 因子が抽出され た. そして，これらの因子の評価に治療者の属性として 何が影響を与えているか, できるだけ多く抽出し（立場, 年齢, 性, 守門, 経験, 技法, 臨床場面, 治療レベル, 対象, 治療形態, 診断, 教育分析), その関係を調べた. その結果, 専門, 立場, 技法, 対象が多くの因子と関係 深く, 多少関係が見られたのが年齢, 経験, 治療レベル であった.しかし，この結果はクライエントの動きを表 わす因子が精選されて和らず, 全体を統一した視点から 把握することができなかった。

この結果をふまえ, 本研究の目的は, まず治療的意味 のあるクライエントの動さの構造を明確化し, 治療過程 に沿って位置づけることにある. そして，次にそれに治 療者の属性がどのように関わっているのか, 特に属性の 個々の群がどのような特徵をもっているのか明らかにす ることにある. 治療者の属性としては, 先行研究におい て最も関係が深い専門，つまり職業的立場を中心に，関 係が見られた属性に性差を加えて分類してみた.今回, 職業的立場を中心においたのは, 日本における心理臨床 
の現場に心るる特徵を明らふにしようとする意図もある。

$$
\text { 方法 }
$$

被調查者 心理臨床に従事している治療者と学習中の 者 400 名に調査を依頼した．回答者数 201 名であった. 201 名の被調查者の職業的立場とその人数は以下の通り である、精神科医 (PA) 10 名, 病院のクリニカル・サ イコロジスト (CP) 25 名, 児童相談所の相談員 (CC) 45 名, 大学のカウンセラー (UC) 13 名, 教育相談所 の相㪣員 (EC) 25 名, 教師 (T) 15 名, 家庭裁判所の 調査官 (FE) 25 名, ケース・ワーカー (CW) 15 名, その他のカウンセラー (OC) 14 名, 学習中の者 (S) 14 名, 計 201 名である. また，この 201 名の者は，そ の他の曷性について Table 1 のように分類された.

質問項目 小川・永井（1980）で作製した治療的意味 のあるクライエントの動きを表わす形容詞・形容動詞の 項目再吟味し，47項目として，治療的意味がない，か ら非常に意味がある，むでの 6 段階評定とした。

\section{結果}

\section{1. 治療的意味のあるクライエントの動きの構造}

201 名の 47 項目に対する評洒得点から，47 項目につ いての相関行列を算出し，それをるとに主因子解を求 め, ヴァリマックス回転により 7 因子を抽出した.

a. 因子の結果 各因子の内容を明らかにするために 因子負荷量 . 400 以上の項目を選び, 負荷の高いものか ら書いてみると以下の通りである.

第 1 因子： (36いらいらした(. 845), (39)不安定な(.797), (28)反抗的な (.788), (12)挑戦的な (.763), (20)切迫した (.656), (9よりかかってくる (.639), (24いな特った (.638), (6)じっぱりな (.628), (31深刻な (.621), (3) はげしい(.613), (8)迷っている (.612), (45)自己に沈潜 した (.525)，(7)こら党ている (.509), (411ぶつかってく る(.472), (26)きびしい (.444).

第 2 因子：(444はききとした (.744)，(43)協力的な (.728)，(16親しみのある(.726), (10)話しやすい(.720)， (32)好意のある (.693), (33)はっきりした (.562), (111責任 ある(.556), (22)暖かい(.543), (15)理性的な (.508), (21) 落らついた (.469), (30)素直な (.443), (42)ゆったりとし た (.442)，(16)楽な (.441)，(22)いきが合った (.432).

第3 因子：(29)自分を受け入れられる (.700), (30自律 的な(.575)，(40)自分なりの (.570)，(40)自発的な (.484)， (38)生き生きとした (.462)，(27)意欲的な (.400).

第 4 因子：(18)自然な (.603)，国深みのある (.563), (19)心が開いた (.558)，(23)爰かい(.524).

第 5 因子：(1)前向きの (.630), (27)意欲的な (.570), (5)力強い (.533), (2)明るい(.501), (14)たくましい (.460)，（11)責任ある (.427).
算6因子：䒚余裕のある(.661)，国ゆったりとした (.552)，(13)やわらかい (.500), (46)楽な (.439).

第 7 因子： 17するどい(.679)，(4)敏感な (.669)，(26) きびしい(.417).

\section{b. 因子の命名}

第 1 因子：この因子の表わすクライエントの動さは, (36), (39), (20), (31), (8), (7)などの項目によって表わされる 葛藤による混乱・動摇を示している動きとともに, (28), (12)，(24，(6)，(411)，(26)などの項目によって表わされる攻擊 的かつ反抗的な動さを表わするのと考兄られ，クライエ ントの抵抗や内的暮藤の動きと命名した.

第 2 因子：この因子では, (44), (39)，(11)，(15), (21)な゙の 項目で表方される安定感がもてるよらになる動きと, (43), (16), (10), (32), (23), (222などの項目で表わされる他者と 心が通じ合った信頼感がもてるようになる動きと考えら れ, クライエントの安定した信頼関係をつくろらとする 動きと命名した.

第 3 因子：この因子では，(29，(30，(40など自分自身の あり方をもつことができる動きと，(477，(38)，(27)などの外 に積極的に向かって行こうとする動きを表わすと考えら れ，クライエントの自律性の動きと命名した.

第 4 因子：4つの項目の表わすクライエントの動き は，あるがあまに自分の姿を開き認めるようになる動き と考えられ，クライエントの心が開かれる動きと命名し た.

第 5 因子：全体的にこの因子の含も項目は，前向きに 積極性をもって取り組もうとする動きと考光られ，クラ イエントの積極性の動きと命名した.

第 6 因子：4つの項目は，共通して心の中にゆとりが もてるような動きと考兄られ，余裕がもてるようになる 動きと命名した。

第 7 因子 : 項目が 3つと少なく，これだけで命名する ことには困難さもあるが，3つともある種の緊張感を示 している動きと考えられ，緊張感の高まりを示す動きと 命名した.

\section{2. 因子の評価と治療者の属性の関係}

a. 各因子と7つの属性の関係 抽出された 7 因子に 対する評価に, 治療者のもつ属性の何が影響を与えてい るか，その関係を林の数量化 I類によって明らかにし た. 偏相関係数.300 以上を関係がある属性として挙げ てみる.

第 1 因子:なし. 第 2 因子: 経験年数 $(r=.344)$, 職 業的立場 ( $r=.337)$. 第 3 因子 : 職業的立場 $(r=.327)$. 第 4 因子 : 職業的立場 $(r=.301)$. 第 5 因子 : 経験年数 $(r=.302)$. 第 6 因子 : 職業的立場 $(r=.374)$, 経験年 数 $(r=.357)$. 第 7 因子 : 職業的立場 $(r=.307)$. 以上 のように, 治療者の属性の中で職業的立場と経験年数が 各因子の評価に強い影響を与えていることが明らかとな 
った.

b. 治療過程から見た各因子の位置 次に, 治療者の 各々の属性が，クライエントの動きの評価にどのような 特徵をもっているのか明らかにするために, 抽出された 7 因子の表わすクライエントの動きが，治療過程から見 た場合, ぞのよらな順に出現すると考えられるか明らか にした. 本調査を和願いした 22 名の治療者（精神科医 3 名, 病院の CP 5 名, 児相の相談員 5 名, 教相の相談 員 5 名, 大学のカウンセラー 4 名) に, 各因子のクライ エントの動きの出現順位を決めてもらった. 各因子の平 均順位は，次のようであった。第 1 因子 (2.05), 第 2 因子 (3.00)，第 3 因子 (6.18)，第 4 因子 (4.09)，第 5 因子（5.55），第 6 因子（5.27），第 7 因子（1.86）,

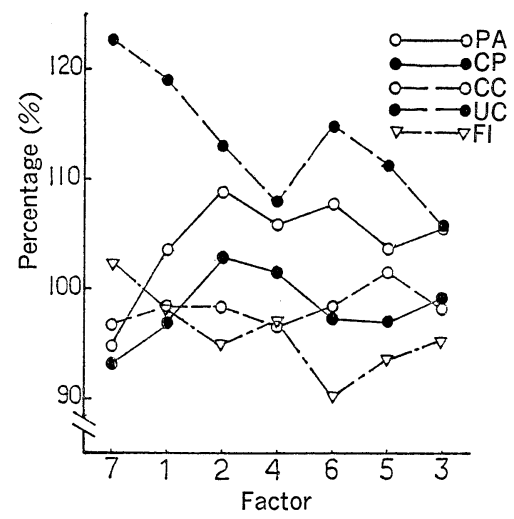

Fig. 1-a. The average estimate of seven factors by professional position. PA : Psychiatrist. $\mathrm{CP}$ : Clinical psychologist. CC: Counselor of the child consultation. UC: Counselor of the university. FI : Investigator of the court of family affairs.

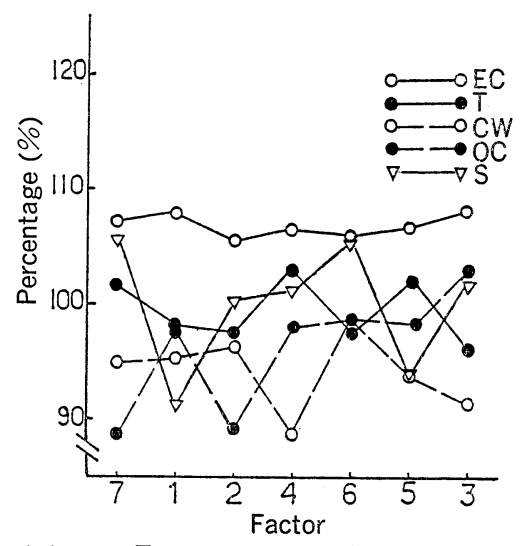

Fig. 1-b. The average estimate of seven factors by professional position. EC : Counselor of the educational consultation center. $\mathrm{T}$ : Teacher. $\mathrm{CW}$ : Case worker. OC : Other counselor. S : Counseling student.
以上の結果より, 治療過程の中でクライエントの動き は，第 7 因子，第 1 因子，第 2 因子，第 4 因子，第 6 因 子, 第 5 因子, 第 3 因子の順に現われると位置づけられた.

c. 治療過程における各属性の評価 次に, 治療過程 に沿って位置づけられたクライエントの動きを表わす各 因子について, 治療者の属性の個々の下位群がどのよう な評価をしているのか明らかにした。 つまり，個々人に ついて各因子ごとの項目の評価得点を求め, 属性の下位 群別の評価得点の平均を求めた. そして, 被調査者全員 の各因子についての評価得点の平均に対する属性の下位 群の比率を求め図示し, 治療過程に批汸各属性の下位 群の特徵を明らかにした。

Fig. 1-a，1-b は，職業的立場に和ける個々の群の各 因子についての評価を治療過程に沿って示したものであ る. Fig. 1-a より大学のカウンセラー (UC) は全般的に 評価が高いが, 治療過程の初期の, 第 7 因子, 第 1 因子の 評価が特に高く, 中期の第 4 因子までの評価が低くなっ ている. 精神科医 (PA), 病院のクリニカル・サイコロ

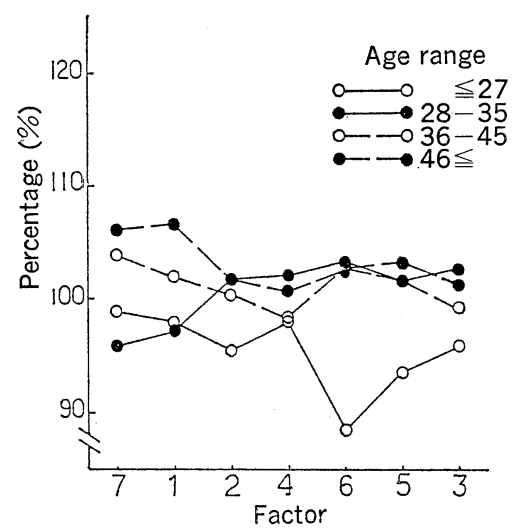

Fig. 2. The average estimate of seven factors by age of the therapist.

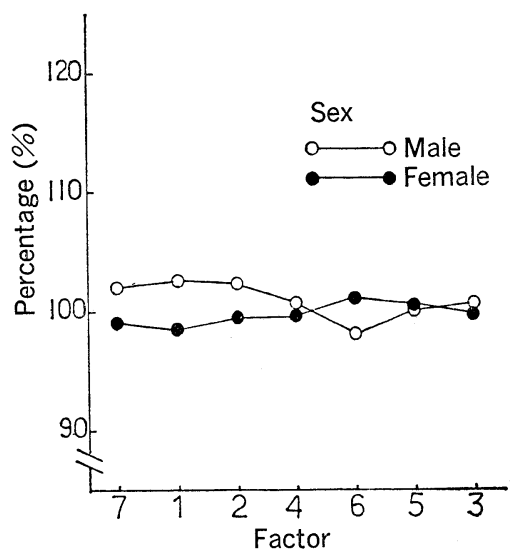

Fig. 3. The average estimate of seven factors by sex. 
ジスト (CP) は, 逆に初期の第 7 因子, 第 1 因子の評価 が低く，その後の因子の評価が高くなっている. 家庭裁

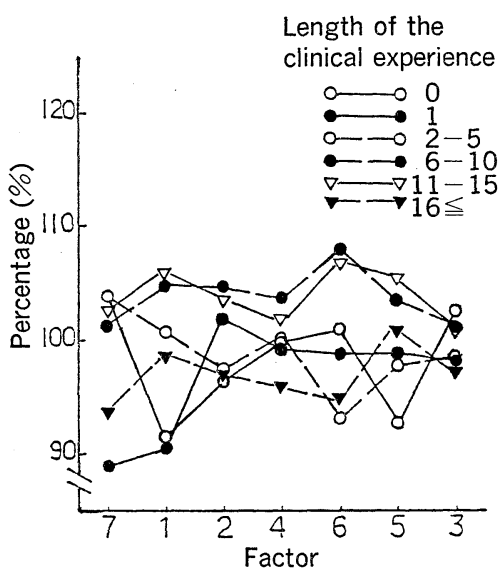

Fig. 4. The average estimate of seven factors by clinical experience.

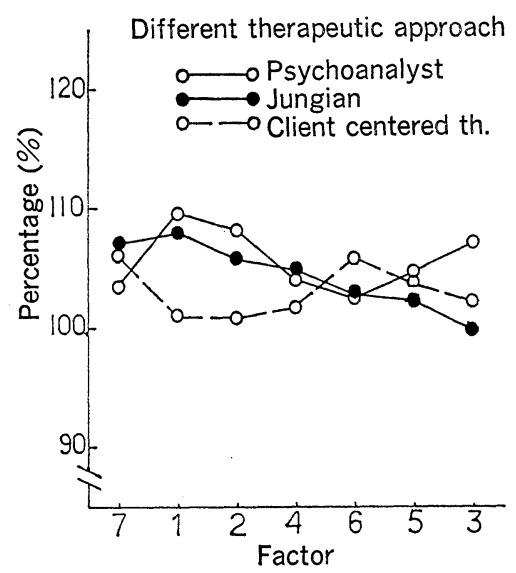

Fig. 5. The average estimate of seven factors by therapeutic approach.

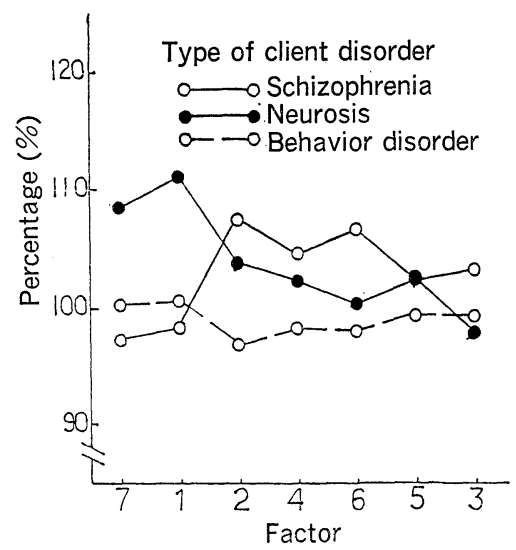

Fig. 6. The average estimate of seven factors by type of client disorder.
判所の調査官 (FI) は，第 6 因子，第 5 因子，第 3 因子 など後期の評価が低かった. 児童相談所の相談員 (CC) や Fig. 1-b の教育相談所の相談員 (EC) は, 全般的に ほぼ一定した評価をしていた. 教師 (T) の場合, 後半 の因子の評価に大きなばらつきが見られた。ケース・ワ 一カー (CW) の場合, 中期の第 4 因子と終結期の第 5 因 子, 第 3 因子の評価が低くなっている. 学習中の者 $(S)$ に打いては，前半と後半に大きな評価のばらつきが見ら れた。 その他のカウンセラー $(\mathrm{OC})$ では, 後半に高い評 価が見られた。

Fig. 2 は，治療者の年齡別に各因子の評洒を示したも のである. 27 歳以下の場合, 第 6 因子, 第 5 因子など後 期の評価が非常に低くなっていた，28一35 歳の場合， 第 7 因子，第 1 因子の評価が低く，その後の因子の評価 は上昇している. 36-45 歳や 46 歳以上の場合は, 第 2 因子，第 4 因子など中期の評価が低くなっていた.

Fig. 3 は，性差についての評価を示しているが，男女 とも際立った特徵は見られなかった。

Fig. 4 は, 経験年数別の評価を示している. 未経験者 は, 職業的立場の学習中の者とほぼ重なり評価も同じ形 を示している. 1 年以下の者は, 初期の第 7 因子, 第 1 因子の評価が非常に低い傾向が見られた．2-5 年の者 は，逆に初期の評価は高く，後半の因子の評価が低くな っていた. 6-10 年と 11-15 年の者は, ほぼ同じ評価 を示し初期と後期に比べ，中期の第 4 因子の評価が低か った. 16 年以上では, 全般に低いが前期と後期に評価が 高くなる形を示していた.

Fig. 5 の治療的アプローチでは，3群を図示してみた. 精神分析とユング派では, 初期から中期にかけて同じ評 価をしているが，後期の第 5 因子，第 3 因子に拉ける評 価に違いが見られ, 精神分析の場合は評価が高くなる が，ユング派では低くなっていた．来談者中心療法の治

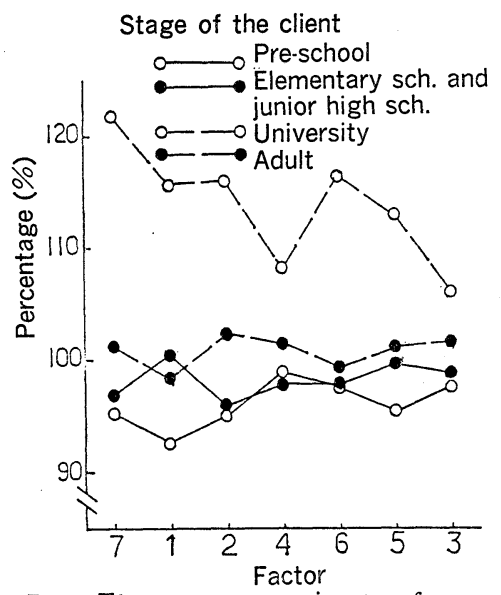

Fig. 7. The average estimate of seven factors by stage of client. 
療法は，初期の第 7 因子と後期の第 6 因子の評価が高 く，その間の評価が低くなっていた。

Fig. 6 は, 治療者が主に接しているクライエントの障 害の種類であるが, 分裂病の場合は初期の第 7 因子, 第 1 因子と後期の第 5 因子，第 3 因子の評価が低かった. 逆に, 神経症の場合は初期の第 7 因子, 第 1 因子の評価 を非常に高くしていた. 問題行動の場合る初期の 2 因子 の評価が多少高い傾向が見られた.

Fig. 7 は, クライエントの年齢別であるが, 大学生を 主にみている治療者の評価が全般的に高く，これは職業 的立場に拈ける大学のカウンセラーと重なっている. 小 ・中学生を主にみている治療者は, 第 1 因子の評価が多 少高い傾向が見られた. 未就学児の場合は, 初期の評価 が低かった，成人の場合，第 1 因子が多少低いが，ほぼ 全体の平均と一致した評価をしていた。

\section{考察}

\section{1. 治療的意味のあるクライエントの動きの構造}

47 項目について因子分析の結果, 7 因子が抽出され た. 各因子の内容については, 結果の因子の命名のとこ ろで考察しているので，ここでは触れないが，小川・永 井（1980）の中で抽出された因子に比べ，項目の再吟味 がされているため，因子の構造が明確化し，実際の治療 状況の中で具体的なイメージをもつことのできるクライ エントの動きを表わす因子が抽出できたと考えられる，

しかし，第 4 因子，第 6 因子，第 7 因子に沶いては，抽 出された項目が少ないため, 因子の命名に多少困難な部 分もあった.

\section{2. 因子の評価と治療者の属性の関係}

a . 各因子亡7つの属性の関係 本研究で選択した属 性は，先行研究で関係が見られた属性について分析した のであるが，関係が見られたのは職業的立場と経験年数 だけであった。このような結果の原因としてまず考えら れる点は, Table 1 を見るとわかるよらに治療的アプロ 一チの場合, その他が 100 名と半数を占めて和り, 障害 の種類に括いても, 問題行動 94 名, その他 57 名を占め ており，この中に含まれる人は幅広く種々の立場がある ため, 数量化 I 類の偏相関係数の值が低くなったと考え られる.さらに関係が見られなかった年齢, 治療対象に おいては，それぞれの下位群の各因子についての評価得 点を分散分析した場合，年齢では第 1 因子，治療対象に 揖いては第 2 因子に有意差傾向が見られ，分析方法によ っては関係のない属性とは言い難いとも考えられた. し かし，このような統計的な分析上の問題とともに，クラ イエントの動きの評価といら質問紙によって，治療者の 属性の違いが，ぞの程度反映されるかという，質問紙に よる限界も考えておく必要がある。つまり，このような 方法では, 職業的立場や経験年数によって形成される要
因が反映されやすいとも考觉られる.

b. 治療過程から見た各因子の位置 治療過程に沿っ て位置づけられた 7 因子のクライエントの動きを, 実際 の治療過程に沿って考えてみることにする. まず，クラ イエントは何らかの問題をかかえて治療者を訪れる. 初 めて出会う治療者に対し, そして自らの問題に治療関係 の中で直面しなければならないことに，クライェントは 第 7 因子の表わす緊張感の高まりを示すものと考兄られ る.そして，しだいに第 1 因子の表わす治療者に対する 抵抗や自分自身の中での内的葛藤の動きを通して, 自ら の問題が明らかとなる. そのよらなクライェントの不安 定な動きを治療者が共感し理解してあげることで, しだ いにクライエントは治療者に対し, 第 2 因子の表わす安 定した信頼関係をつくろらとする動きを見せるようにな る. そのような治療関係の中から，しだいにクライェン トは第 4 因子の表わす心が開かれる動きを示し,さらに 第 6 因子の表わす余裕がもてるようになる. そして, 最 終的には, 外界に対して自らの持てる力を充分に発揮で さるよらな第 5 因子の表わす積極性の動きや，第 3 因子 の表わす自律性の動きが出現してくる，以上のよらに, 7 因子の表わすクライエントの動きは, 治療過程の初期 から終結期をでの全過程を含んでいると考えられる.

c . 治療過程における各属性の評価 職業的立場に括 いて, 大学のカウンセラーは全般的に評価が高く, 特に 治療の初期から中期の評価が高い傾向が見られた. これ はクライエントの年龄が大学生を主にみている治療者と 重なっている. 大学生との治療の場合, 青年期のアパシ 一などの問題に代表される他者との真の信頼関係を結ぶ ことがでさないといら問題が反映されているために，初 期のクライエントの動きを高く評洒しているものと考え られる. 精神科医や病院のクリニカル・サイコロジスト は初期よりも中期・後期の評価が高くなっている. 初期 の評価が低いのは, 病院といら状況によって守られてい るため，第 7 因子，第 1 因子などの否定的な動きには， 投薬などによって安定をはかろうとするため, 心理療法 上での評価が低いと考えられる，児童相談所の相談員や 教育相談所の相談員は, 治療の後期の評価が多少高くな っているが泳ぼ全体としては一定しており, 臨床の場が 類似の治療者は, 類似の評価をしていると考えられる. 家裁の調查官やケース・ワーカーでは, 治療の中期から 後期にかけての評価が低い.これは, その職業的立場 上, 心理療法としての関わりに限界があるためと考えら れる. 教師の場合, 全般的に評価のばらつきが見られ, また学習中の者においても大きなばらつきがあった，学 習中の者の場合, 本研究で用いた質問に対し経験がない ために,クライエントを一貫した視点をもって評価する ことができないためと考えられる.

年齢では, 27 歳以下の治療者が後期の評価が非常に低 
い.これは経験が少ないために，この段階のクライエン 卜の動きを評価する余裕がないためと考えられる，それ に対し，年龄が増すにつれて治療前期と後期に山があ り，中期で多少低くなる形の評価をしている。

経験年数においても, 経験年数が増すにつれ山が前期 と後期にある同じ形の評価をしていた．未経験者は職業 的立場の学習中の者と重なっている. その特徴について は前に述べた通りである. 1 年以下では，初期の評価が 低い。これは，表面的には否定的に見えるクライエント の動きの中にある意味を理解できていないためと考兄ら れる.

性差に拈いては，特徵的な違いは見られなかった，実 際の治療で大きな影響のある性差の特徵は，本研究のよ

うな質問紙では明らかにすることはできなかった。

治療的アプローチに执いては，精神分析とニング派で は，ほぼ類似の評価を示しているが，終結期の評価が異 なっている，治療契約や治療構造を重視する精神分析の 場合, 最初から明確に終結期を考えているため, 評価が 高くなると考兄らる，それに対しニング派では，個人 の内的な成長を重視しているため，終結期のある面で外 界を向いた動きの評価が低くなっていると考学られる。 来談者中心療法の場合は, 最初の出会いの重視之個人の 肯定的な動きを高く評価している。しかし，抵抗や葛藤 などの動きの評価は低く，精神分析やニング派とは異な っている. 治潦的アプローチの場合，2つ以上の立場を 選択した者を含むその他の者が 100 名と半数を占めたこ とは, 日本の臨床の現場に叔ける治潦の理論や技法が, 非 常に折哀的な形で取り入れられている特徴を示している.

障害の種類では, 分裂病を主にみている治療者は初期 と終結期の評価が低くなっている，これは，分裂病の場 合, 前期の第 1 因子や第 7 因子の動きは, 自我の弱い分 裂病の患者にとってはかえって危険な動きと考学られる ためである、また完治することが難しいため，終結期の 評価が低くなっているものと考兄られる。 それに対し， 神経症の場合, 第 1 因子の表わすような抵抗や内的葛藤 をいかに克服するかといらことが，最も重要な課題であ るために，この動きの評価が高くなっていると考えられ る. 問題行動の場合も, 神経症と同じように考兄られた.

クライエントの年齡では, 大学生を主にみている治療 者に特徵的な傾向が見られたが，これは前に述べた通り である。

\section{引用 文 献}

Berzins, J. I., \& Seidman, E. 1968 Subjective reactions of $\mathrm{A}$ and $\mathrm{B}$ quasi-therapists to schizoid and neurotic communications. Journal of Consulting and Clincal Psychology, 32, 342-347.

Berzins, J. I., \& Seidman, E. 1969 Differential therapeutic responding of $\mathrm{A}$ and $\mathrm{B}$ quasi-therapists to schizoid and neurotic communications. Journal of Consulting and Clinical Psychology, 33, 279-286.

Berzins, J. I., \& Ross, W.F. 1972 A-B therapist distinction, patient diagnosis and outcome of brief psychotherapy in a college clinic. Journal of Consulting and Clinical Psychology, 38, 231-237.

Fiedler, F.E. 1950 A comparison of therapeutic relationships in psychoanalytic, nondirective and Adlerian therapy. Journal of Consulting Psychology, 14, 436-445.

河合隼雄 1982 Jung のタイプ論に関する研究——文 献的展望— 京都大学教育学部紀要, 28, 1-15.

King, D. G., \& Blaney, P. H. 1977 Effectiveness of $A$ and $B$ therapists with schizophrenics and neurotics: A referral study. Journal of Consulting and Clinical Psychology, 45, 407-411.

McNair, D., Callahan, D., \& Lorr, M. 1962 Therapist "type" and psychotherapy. Journal of Consulting Psychology, 26, 425-429.

西園昌久 1974 薬効と治療者患者関係 精神科薬療基 金研究年報 第 6 集 180-186.

小川捷之 ・河合隼雄 - 原野広太郎 - 伊東恵子・小川洋子 1969 心理療法に怙訬る治療者のタイプと治療技法 臨床心理学研究, 8, 165-176.

小川捷之・永井 撤 1980 Psychotherapist の属性に 関する研究——臨床場面に怙いて出現してくる client の動きとその評価について——横浜国立大学 教育学部紀要, 20, 78-103.

Strupp, H. H. 1955 An objective comparison of Rogerian and psychoanalytic techniques. Journal of Consulting Psychology, 19, 1-7.

Whitehorn, J. C., \& Betz, B. J. 1954 A study of psychotherapeutic relationships between physicians and schizophrenic patients. American Journal of Psychiatry, 111, 321-331.

Whitehorn, J. C., \& Betz, B. J. 1957 A comparison of psychotherapeutic relationships between physicians and schizophrenic patients when insulin is combined with psychotherapy and when insulin is used alone. American Journal of Psychiatry, 113, 901-910.

Whitehorn, J. C., \& Betz, B. J. 1960 Further studies of the doctor as a crucial variable in the outcome of treatment with schizophrenics. American Journal of Psychiatry, 117, 215-223.

Witzing, J.S. 1978 Jung's typology and classification of the psychotherapies. Journal of analytical Psychology, 23, 315-331.

-1983.5.13. 受稿, 1984.5.12. 受理一 